\title{
Extent of adoption of recommended practices of pulses through FLD
}

\author{
*Beena Singh** Dr. Y. K. Singh, Mr. Tushar kant Panigrahi \\ * Ph.D. Research Scholar, Mahatma Gandhi Chitrakoot Gramodaya Vishwavidyalaya Chitrakoot-Satna (MP) \\ ** Associate professor, Department of Transfer of Technology, faculty of Agriculture M.G.C.G.V Chitrakoot \\ Satna (MP) \\ Ph.D Research scholar Matatma Gandhi chitrakoot gramodhaya vishwavidhyala chitakoot satna. M.P.
}

\begin{abstract}
FLD programme sponsored by ICAR through KVKs is in operation in MP under the jurisdiction of each KVK. The level of adoption of improved production technology practices on pulses crops (50.00 per cent was medium, 43.33 per cent high and 8.33 per cent low. The maximum adoption level was reported in practice like selection of high yielding varieties 90.00 per cent). the study has been conducted in Chhindwara district of Madhya Pradesh out of 11 blocks the Mahkhed block has been selected purposively with 60 respondents.
\end{abstract}

Key words: Production technology, adoption score, pulses

\section{Introduction}

Pulses constitute an integral part of human diet as it cater the protein requirement of majority of human beings. Besided providing energy, they also supply certain essential amino-acids, minerals and vitamins which are crucial for normal growth and health.

India is a largest producer of pulses in the world with 28 per cent share in global production chick pea, pigeon pea, mungbean, urdbean, lentil and field pea are important pulses crop contributing 39 per cent, 21 per cent, 11 per cent, 10 per cent, 7 per cent and 5 per cent during 2010-2011, the total production was estimated 17.29 million tones.

In the view of FLD with the main objectives is to demonstrate latest location specific technologies of agriculture and allied are among the farming community for enhancing the production and productivity for generating data along with the feedback.

FLD on pulses has fabulous impact not only the farmers adopting but also on nearby farmers. A number of FLDs were carried out by the KVK, Chhidwara on pulses crops especially pigeon pea and gram.

The KVK,Chhindwara were conducted the FLDs on various crops with package of practices during last five year covered 67.6 ha area.

\section{Methodology}

The Study has been conducted in Chhindwara district of Madhya Pradesh. out of 11 blocks the Mahkhed block has been selected purposively. three villages have been selected for the study. On basis of maximum demonstrations conducted under pulses crops adopted by KVK under FLD. Total number of respondents were 60 ,from each village 20 respondents are selected for the study. The data were collected through pre-struchered interview schedule and personally interviewed.percent and rank used for analysis.

\section{Result \& Discussion}

The data was presented in Table-11 show that most 48.34 per cent of the respondents were from medium adoption scores remaining 43.33 per cent and 8.33 percent respondents were from high adoption and low adoption of pulses production technologies.

Table-1 Distribution of FLD beneficiaries according to their adoption score

\begin{tabular}{|l|c|c|}
\hline Categories & Frequency & Percentage \\
\hline Low & 05 & 8.33 \\
\hline Medium & 29 & 48.34 \\
\hline High & 26 & 43.33 \\
\hline Total & 60 & 100.00 \\
\hline
\end{tabular}

The data presented in Table-22 show that first preferences to selection of high yielding varieties 90.00 per cent while the second rank 80.00 per cent time of harvesting, while the third rank 78.33 per cent use of culture, fourth and fifth rank 76.67 per cent and 75 per cent control of insect/pest and disease management, while the six,seven and eight rank 73.33 per cent, 68.33 per cent, 66.67 per cent precaution before storage, 
application of fertilizers and seed treatment remaining 58.33 per cent, 53.33 per cent, 50.00 per cent, 46.67 per cent, 41.67 percent, 40.00 per cent, 38.33 per cent, 36.67 per cent selection of land, crop rotation, time of sowing/seed rate, land preparation, depth of sowing/spacing,weed management, irrigation management and sowing method.regarding improved pulses production technology.

Table-2 extent of adoption for respondents towards pulses production technology

\begin{tabular}{|l|l|l|l|l|}
\hline S.No. & Improved technologies & Frequency & Percentage & Rank \\
\hline 1. & Selection of land & 35 & 58.33 & 9 \\
\hline 2. & Land Preparation & 28 & 46.67 & 12 \\
\hline 3. & Crop rotation & 32 & 53.33 & 10 \\
\hline 4. & Selection of high yielding varieties & 54 & 90.00 & 1 \\
\hline 5. & Seed treatment & 40 & 66.67 & 8 \\
\hline 6. & Time of sowing/seed rate & 30 & 50.00 & 11 \\
\hline 7. & Depth of sowing/spacing & 25 & 41.67 & 13 \\
\hline 8. & Sowing method & 22 & 36.67 & 16 \\
\hline 9. & Use of culture & 47 & 78.33 & 3 \\
\hline 10. & Application of fertilizers & 41 & 68.33 & 7 \\
\hline 11. & Irrigation management & 23 & 38.33 & 15 \\
\hline 12. & Weed management & 24 & 40.00 & 14 \\
\hline 13. & Control of insect/pest & 46 & 76.67 & 4 \\
\hline 14. & Disease management & 45 & 75 & 5 \\
\hline 15. & Time of harvesting & 48 & 80.00 & 2 \\
\hline 16. & Precaution before storage & 44 & 73.33 & 6 \\
\hline
\end{tabular}

\section{Conclusion :}

the level of adoption of improved production technology practices on pulses crop was medium. the maximum adoption level was reported in practice like 'selection of high yielding varities'. This was followed by the practice like 'time of harvesting', 'use of culture', 'control of insect/pest', 'disease management', 'precaution before storage', 'application of fertilizers', 'seed treatment', 'selection of land', 'crop rotation', 'time of sowing/seed rate', 'land preparation', 'depth of sowing/spacing', 'weed management' respectively, while practices like "irrigation management", and "sowing method" were having less adoption level by the respondents.

\section{Reference}

[1]. A.D. Raj (2013) "Impact of FLD on the yield of Pulses. Gujarat, India International journal of scientific and research publications, volume 3,

[2]. Jatav, H.R. (2010) "A Study on impact of FLD on scientific temperament of wheat growers in Indore and Dewas, district (M.P.), M.Sc.(Ag.) thesis RVSKVV, Gwalior.

[3]. Singh, A.K. (2009) "A Study on impact of oilseed FLD in adoption of production technology by farmers in Tikamgarh District (MP)' M.Sc. (Ag.) thesis,JNKVV, Jabalpur. 